\title{
Benefits from ecological study methods to taxonomy of enchytraeids in southern Mata Atlântica
}

\author{
Rüdiger Maria Schmelz(1), Rut Maria Collado de la Peña(1) and Jörg Römbke ${ }^{(2)}$
}

\begin{abstract}
(1)Universidade da Coruña, Facultad de Ciencias, Departamento de Biología Animal, Biología Vegetal y Ecología, Alejandro da Sota, 1 E-15008 A Coruña, Spain. E-mail: rutco@udc.es ${ }^{(2)}$ ECT Oekotoxikologie GmbH, Böttgerstrasse 2-14, D-65439 Flörsheim, Germany. E-mail: j-roembke@ect.de
\end{abstract}

\begin{abstract}
The objective of this work was to determine how taxonomy benefited from the ecological quantitative and site-based sampling methods in enchytraeids studies. Enchytraeids (small relatives of earthworms) were sampled in different phases of rain forest regeneration in the southern Mata Atlântica in Paraná, Brazil. The research combined ecological and taxonomic work, because enchytraeids are poorly studied and difficult to identify, and many new species were expected. The provision of large numbers of specimens enabled the test of species diagnoses by investigating the ranges of character variations in a larger series of specimens. Simplified species diagnoses adapted to the local conditions that allowed the identification of all specimens, juveniles included, were developed. Key characters and character states are presented for the three genera: Achaeta, Hemienchytraeus and Guaranidrilus. Among several new species, a rare species, possibly a remnant of the autochthonous forest fauna, was found and described.
\end{abstract}

Index terms: Clitellata, Enchytraeidae, Oligochaeta, South America, species identification.

\section{Benefícios de métodos de estudos ecológicos para a taxonomia de enquitreídeos no sul da Mata Atlântica}

Resumo - O objetivo deste trabalho foi determinar como a taxonomia beneficia-se de métodos quantitativos e de amostragem ecológicos nos estudos dos enquitreídeos. Enquitreídeos (pequenos parentes das minhocas) foram coletados em diferentes fases de regeneração da Mata Atlântica no Estado do Paraná, Brasil. Foram combinadas as pesquisas ecológica e taxonômica, pois os enquitreídeos são pouco estudados e difíceis de identificar, e muitas espécies novas eram esperadas. O grande número de espécimes coletados permitiu testar diagnoses de espécies por meio da investigação das amplitudes de variações de caracteres em uma série mais ampla de espécimes. Diagnoses de espécies simplificadas, adaptadas às condições locais do ambiente, foram desenvolvidas, o que permitiu a identificação de todos os exemplares, incluindo juvenis. Caracteres-chave e estados de caracteres foram formulados para três gêneros: Achaeta, Hemienchytraeus e Guaranidrilus. Entre várias espécies novas, uma espécie rara, possível remanescente da fauna autóctone da floresta, foi encontrada e descrita.

Termos para indexação: Clitellata, Enchytraeidae, Oligochaeta, América do Sul, identificação de espécies.

\section{Introduction}

As part of the Brazilian-German cooperative project Solobioma (Project Solobioma, 2009), the quality of secondary Atlantic forests regenerating from degraded areas (mainly pastures) was evaluated to provide recommendations for future management and protection (Höfer et al., 2007). Research activities focused mainly on soil biota and soil processes (Bihn et al., 2008; Schmidt et al., 2008; Römbke et al., 2009), although vegetation and some associated species of the invertebrate fauna were also studied (Liebsch et al., 2007). From the beginning, enchytraeids were included as a supposedly informative group (Römbke et al., 2005). The expectation was that species assemblages of this taxon could be used as indicators for biologically relevant soil parameters, comparable to the indicator function of enchytraeids in temperate regions (Graefe \& Schmelz, 1999). However, the abundance of enchytraeids is usually low in soils at lower latitudes (Römbke, 2007).

Regarding species composition, most of the tropics and subtropics are 'terra incognita', despite some valuable efforts made especially in South America (Römbke, 2007; Christoffersen, 2009). Enchytraeidae 
is a poorly studied and taxonomically complicated family (Schmelz, 2003), with many subgroups in need of revision. On the other hand, ecological studies with Enchytraeidae cannot be postponed until the family's ultimate taxonomic resolution. Moreover, the large amount of specimens sampled in field studies provides excellent opportunities for in-depth taxonomic studies. Therefore, quantitative and site-based (ecological) investigations should be combined with qualitative and specimen-based (taxonomic) investigations. The benefits of taxonomy for ecological or conservation studies are evident, since taxonomy provides the basic units - well-described nominal species - upon which most of these studies are based (Gotelli, 2004). The reverse is perhaps less obvious.

The objective of this work was to determine how taxonomy benefited from the quantitative and site-based sampling methods in enchytraeids studies.

\section{Materials and Methods}

Investigations were carried out between May 2003 and January 2008 in southeastern Paraná State, Brazil, in the environmental protection area of Guaraqueçaba. This represents the largest continuous piece of the severely threatened and fragmented Brazilian Mata Atlântica (Myers et al., 2000). Fifty-one study sites were investigated in two areas: the Reserva Natural Rio Cachoeira and the Reserva Natural do Itaquí. Both sites are owned by the regional NGO Sociedade de Pesquisa em Vida Selvagem e Educação Ambiental (SPVS). The sites were selected to reflect a gradient of human influence and of forest regeneration from pasture/cultivated land to old-growth forest. Maps and further information on study area, sampling sites, sampling design, taxa studied and parameters investigated are available in Bihn et al. (2008) and Römbke et al. (2007, 2009). A few additional samples were taken from a grazed pasture inside the campus of Setor de Ciências Agrárias at Universidade Federal do Paraná, in Curitiba.

Samples were taken with a coil corer according to the International Organization for Standardization (2006) standard. For convenience and also because of the well-known severe Brazilian legislative restrictions concerning the exportation of living material, extraction and investigation of living material took place in the country itself. Extraction was carried out using the wet funnel method without heating (International Organization for Standardization, 2006). To minimize oxygen stress, samples were submerged in a large volume of water ( $2 \mathrm{~L}$ for a $5-\mathrm{cm}$ column with a 5.6-cm diameter), and water was changed after 24 hours in mineral soil samples. The maximum extraction time was of three days; after four or more days, the amount of damaged specimens increased. Oxygen stress is a problem in warmer climates, because enchytraeids lack blood capillaries and take up oxygen only from the body surface; on the other hand, cooling the water is not recommended in species adapted to higher temperatures.

Subsequent procedures involved two steps: 1, obtaining qualitative (taxonomic) and quantitative (ecological) data in a single working process; 2, separate taxonomic and ecological data analysis. This paper deals mainly with the taxonomic aspects of these two steps. Preliminary results for the ecological data analysis at the family and genus levels can be found in Römbke et al. (2007).

At step 1, specimens were investigated and identified immediately after in vivo extraction by means of a light microscope and by gently pressing the specimens between slide and coverslip in a drop of water. With careful handling and renewal of water every five minutes, specimens could be studied for more than half an hour without damaging the individuals. Such a long time was necessary especially at the beginning, when almost all species were new and character states were not established yet. Enchytraeids are best identified in vivo, especially at sites with unknown species composition; some taxonomically useful characters are visible only in living specimens. A catalogue of circa 20 characters was screened in each individual to sort the morphotaxa and to assess character variations. Unknown genera or species were given informal names, such as "Genus $X$ " and "Achaeta 7", which are to be replaced with nomenclaturally valid names in the framework of forthcoming descriptions. Each morphological variant was given an informal name, an option for splitting rather than for lumping. All specimens found in a sample were investigated. About 2,500 specimens were scrutinized altogether. As a result of this first step, qualitative and quantitative baseline data were obtained simultaneously in a list of informal taxa (morphospecies), separable by light-microscopic characters, together with descriptions and an identification key and datasets specifying the abundance and biomass of each taxon at each of the sampling sites. 
At step 2, after live investigation, specimens were fixed with hot Bouin's fluid and stored after 24 hours in $70 \%$ ethanol. The whole material was deposited in two Brazilian collections: at the Museu de Zoologia of Universidade de São Paulo and at the entomological collection of Departamento de Zoologia of Universidade Federal do Paraná; later the material was loaned for detailed reinvestigations. This part of the work was carried out in Spain and took most of the time. For taxonomic scrutiny, specimens were stained and whole-mounted in Canada balsam between two coverslips and enclosed in an aluminium frame, following the protocol in Schmelz (2003). Further reference material of previously described South American species was loaned for comparison. The first results, with taxonomic revisions and descriptions of new species, are given in Schmelz et al. (2008).

\section{Results and Discussion}

The quantitative sampling method had at least three effects on the taxonomic work. First, the large number of specimens investigated, together with the repeated scrutiny of characters and the need to identify specimens at all stages of development, revealed that a limited number of nonsexual traits was sufficient for a sorting of specimens into taxonomic groups or species. The three principal genera encountered in the samples, which dominate the fauna of the southern Mata Atlântica, were Hemienchytraeus, Guaranidrilus and Achaeta.

Six species of Hemienchytraeus (Figure 1) were found, four of them new. All specimens at the study sites could be identified using only three characters: oesophageal appendage, pharyngeal glands and anterior nephridia. The oesophageal appendage is a symmetrically ramifying system of blind-ending tubes with a common opening dorsally into the oesophagus. Presence, location and general shape are genus-diagnostic, but the pattern and number of distal ramifications are species-specific. The distribution patterns of additional ventro-lateral lobes of the pharyngeal glands and of the nephridia are also species-specific. The latter two traits alone suffice to separate five of the six species encountered. The identity of the species was ascertained using the entire set of characters, reproductive organs included. More than one species may fall under one and the same set of combinations of three characters. For example, one of the new species is indistinguishable from Hemienchytraeus stephensoni (Cognetti) (Schmelz \& Collado, 2007) regarding the three traits mentioned above. The reproductive organs, however, are different. $H$. stephensoni was not found at the study sites.

Over 25 morphotaxa of Guaranidrilus (Figure 2) and related taxa were distinguished, most of them with a hitherto undescribed character combination. Four characters proved sufficient to sort the specimens of Guaranidrilus: 1, presence/absence and density of epidermal gland cells - in Guaranidrilus, these cells are often conspicuously brown and quite long, but the variation pattern is difficult to assess and still under study; 2 , presence/absence of oesophageal appendages - here, a pair of small, ovoid bodies attached to the oesophagus dorso-laterally in segment VI, and without apparent connection with the oesophageal lumen; 3 , distribution pattern of anterior nephridia; 4, extension and shape of intestinal diverticula - a pair of hollow pouches attached laterally to the intestine in segments VII or VII-VIII, whose size and shape, with some variation, are species-specific. The taxonomy of Guaranidrilus is made difficult by several closely related species, also found at the study sites, which blur the distinctions between Guaranidrilus and other enchytraeid genera, notably Tupidrilus and Marionina.

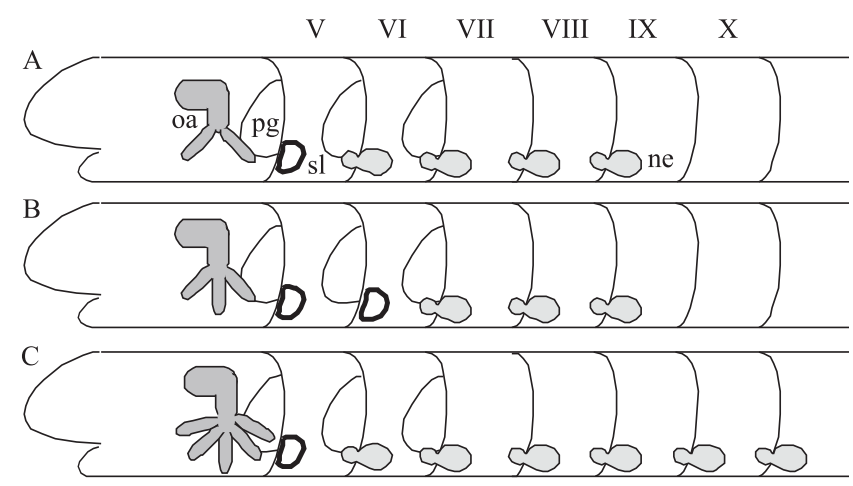

Figure 1. Diagrammatic views of the interior body region of Hemienchytraeus spp. showing species-distinguishing variations of three nonsexual taxonomic characters. oa, oesophageal appendage, dark-grey; sl, secondary ventral pharyngeal gland lobes, bold-bordered; ne, nephridia, lightgrey. A, H. tanjae Schmelz \& Römbke, 2005; B, H. patricii Schmelz \& Römbke, 2005; C, undescribed. The character combinations are species-specific and allow the identification of all specimens, juveniles included. V, VI, VII, VIII, IX and $\mathrm{X}$, segment numbers; pg, pharyngeal glands, primary lobes. 
Five species of Achaeta (Figure 3) were found, three of them new (Schmelz et al., 2008). A complete list of species-separating nonsexual characters is given in Table 1. Only a limited number of traits were necessary for identification. Note that all species were separable by the position of preclitellar nephridia alone. Second, one of the three new species of Achaeta, A. singularis Schmelz, 2008, was represented by a few immature individuals. Recently, a single sexually mature specimen was found and will soon be described. The animals are rather small and would certainly have been overlooked by a purely qualitative sampling design. The finding is important for the objectives of the Solobioma project, because this is the only species of the genus that is restricted to the forest regeneration phases with more than 10-20 years of age (Figure 4). The other species are either indifferent to succession or are restricted to sites under human influence. In phylogenetic terms, some 'aberrant' traits of the nervous system of $A$. singularis (posteriorly incised brain, ganglia of segments II-IV not fused) suggest that this species represents an old branch of this genus, which has a worldwide distribution. Perhaps it represents a sister group to all other Achaeta species. Therefore, it is possible that A. singularis is a remnant of the old autochthonous forest fauna (Schmelz et al., 2008).

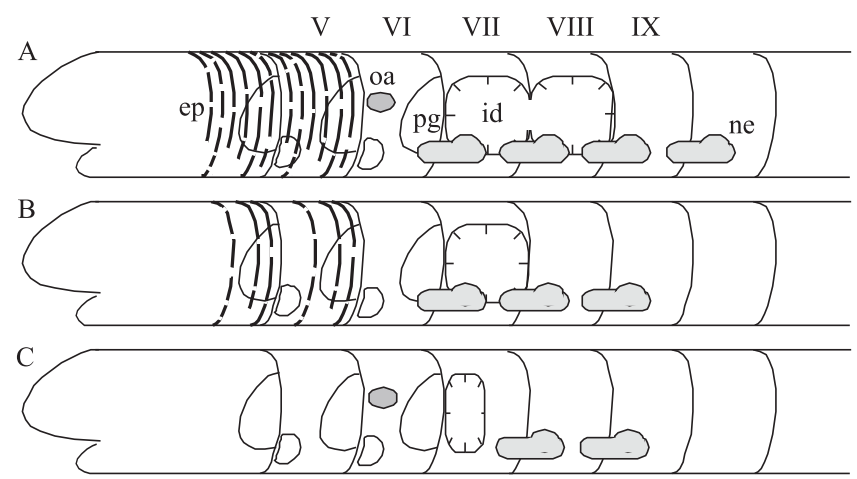

Figure 2. Diagrammatic views of the anterior body region of Guaranidrilus spp., showing species-distinguishing variations of four nonsexual taxonomic characters. ep, epidermal glands (here only in segments IV and V but present also in following segments; $\mathrm{C}$ is without glands), interrupted bold lines; oa, oesophageal appendage in VI, dark-grey oval; id, intestinal diverticula in VII or VII-VIII, bold-bordered; ne, nephridia, light-grey. The character combinations are species-specific and allow the identification of all specimens, juveniles included. The species are still undescribed. V, VI, VII, VIII, IX and X, segment numbers. pg, pharyngeal glands, primary lobes.
Third, high morphological variation was found in a group of specimens identifiable as $A$. neotropica Černosvitov, 1937. All specimens had to be assigned to the same species, A. neotropica, because of the types of gradations and the lack of a clear-cut morphological gap. However, we hypothesized that the species as defined now represents an aggregate of cryptic or incipient species, inseparable with traditional light-microscope methods (Schmelz et al., 2008).
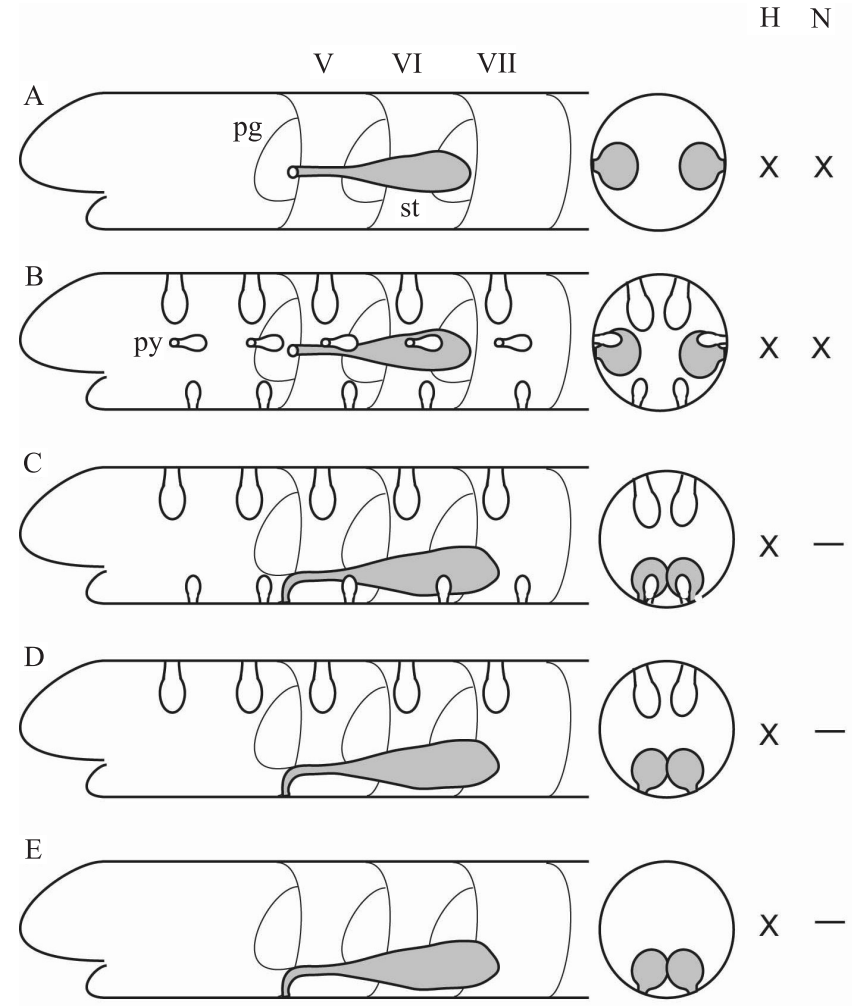

Figure 3. Diagrammatic overview of the five major groups of species in Achaeta using two key characters (spermathecal pores, pyriform glands) and presence of these groups in the holarctic $(\mathrm{H})$ and neotropic $(\mathrm{N})$ ecozones as established after revisionary work in Schmelz et al. (2008). Worms in side view (left, anterior body region) and crosssection (right). A, spermathecal pores lateral, no pyriform glands; B, spermathecal pores lateral, six pyriform glands per segment; C, spermathecal pores ventral, four pyriform glands per segment; D, spermathecal pores ventral, two pyriform glands per segment; E, spermathecal pores ventral, no pyriform glands. $A$. piti, a synanthropic species, belongs to group $\mathrm{B}$, all other neotropical species belong to group A. (A) represents the plesiomorphic condition in the genus. "Modern" Achaeta species appear to be absent in South America (column N). V, VI and VII, segment numbers. pg, pharyngeal glands, primary lobes; py, pyriform glands; st, spermatheca. 
These findings are contrasted by a high morphological homogeneity in Achaeta piti Bittencourt, 1974, another species found at the study sites. Both species are, therefore, not equivalent at the taxonomic level, and extrapolations of their ecological behaviour should be treated differently. For example, the almost ubiquitous presence of $A$. neotropica at the study sites (Figure 4) may be an artefact of the low taxonomic resolution.

The following highlights the importance of revisionary work. Two previously described species of Achaeta were found at the study sites, A. neotropica and $A$. piti, already cited above. However, identification was possible only after reinvestigation of the type material, because the original descriptions were erroneous regarding several crucial details. In $A$. neotropica, the spermathecae are described (Černosvitov, 1937) as opening on the ventral side on the animal (Figure $3 \mathrm{E}$ ), while in reality they open on the lateral side (Figure $3 \mathrm{~A}$ ). And A. piti was described (Bittencourt, 1974) as possessing four segmental pyriform glands (Figure $3 \mathrm{C}$ ), while in reality there are six (Figure $3 \mathrm{~B}$ ).

These corrections, apart from assuring the correct identification of specimens, have also implications for the biogeography and phylogeny of the genus. All currently known species of Achaeta can be assembled under five subgroups, distinguished by the position of the spermathecal openings and by the number of segmental pyriform glands (Figure 3). As a result of the revision (Schmelz et al., 2008), South American species cover only a particular segment of the morphological diversity of the genus: A. piti belongs to group $\mathrm{B}$, while all other species belong to group A. Holarctic species, on the other hand, cover the entire range of morphological diversity. Pyriform glands and ventral spermathecal pores should be considered apomorphic in the genus when compared with the general condition in enchytraeids (pyriform glands absent, spermathecal pores lateral). It therefore seems that there are no "modern" Achaeta species in South America (Schmelz et al., 2008). The construction of an evolutionary sequence from $A$ to $E$ is one of several possible scenarios, with $\mathrm{A}$ as the most plesiomorphic and $\mathrm{E}$ the most apomorphic state.

It has been argued that collaboration of community ecologists and taxonomists is hampered by different approaches and assumptions, although they may share the common goal of assembling an accurate species list for a given region (Gotelli, 2004). From the experience of this work, these difficulties do not exist if both parties are involved in the process of data recruitment from the very beginning. Concerted efforts are for the benefit of both sides. The benefits of taxonomy for ecological or conservation studies are almost self-evident (Gotelli, 2004): taxonomy provides the basic units - well-described nominal species upon which most of these studies are based. Without a resolved taxonomy, field studies that sample, count and identify organisms can make only limited use of their data and have little application beyond the study objective itself. The names of five species are infinitely more informative than the number " 5 ". And often not even the number of species is achieved without taxonomic expertise.

On the other hand, the benefits of ecological or conservation studies for taxonomy are also obvious, although rarely highlighted in the literature. Field studies generate large numbers of specimens from relatively few sites. All individuals must be investigated and as many as possible identified, irrespective of body size and state of maturity. These requirements increase the probability of finding rare and possibly important species; they help, by comparison of mature and immature specimens, to establish a local key that

Table 1. Separation and identification of neotropical species of Achaeta using only nonsexual characters.

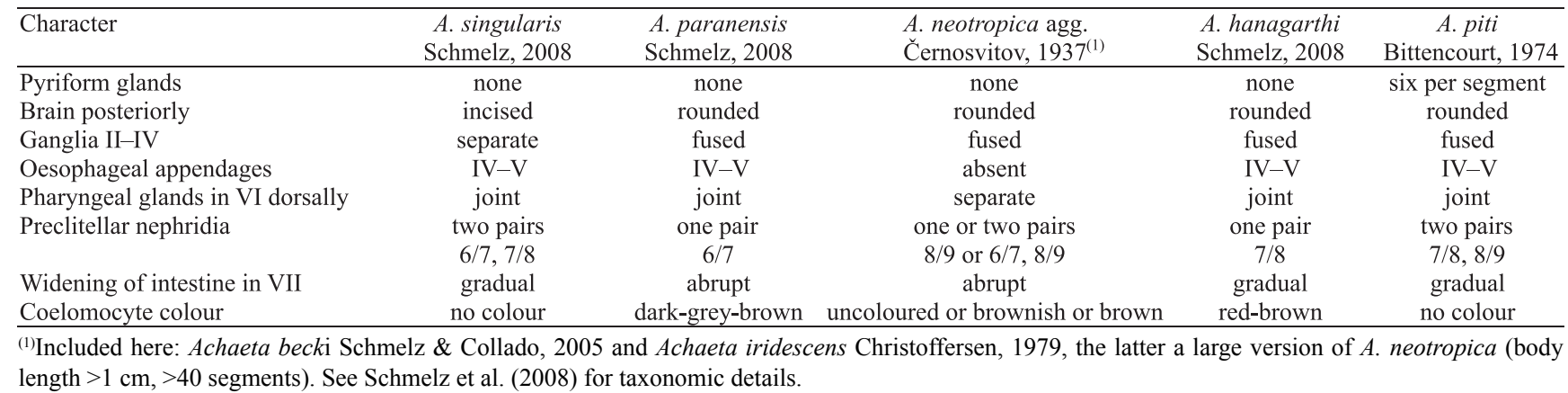



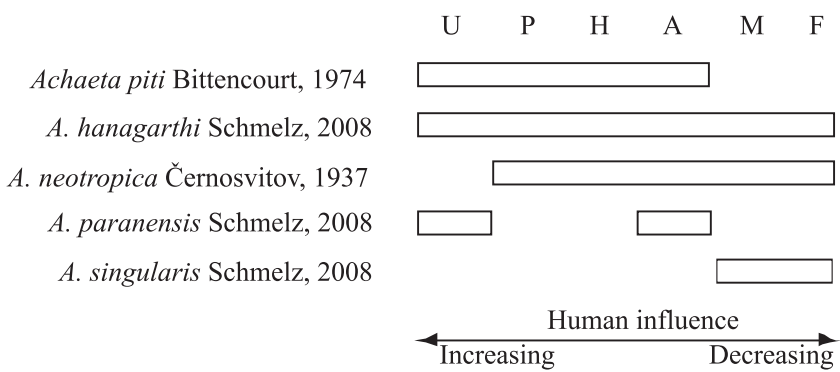

Figure 4. Occurrence of Achaeta species in different habitat types. Human influence is presumed to decrease from left to right. U, urban pasture (Setor de Ciências Agrárias at Universidade Federal do Paraná, Brazil). All others: Solobioma study sites, Cachoeira Natural Reserve. P, buffalo pasture; H, shrubland, pasture abandoned for 3-5 years. A, initial regeneration phase of secondary forest, 10-20 years old. M, medium regeneration phase of secondary forest, $>30$ years old; F, old-growth forest.

allows the identification of all specimens, juveniles included, and they provide an excellent opportunity to test species diagnoses by investigating the ranges of character variation in a larger series of specimens.

\section{Conclusions}

The simultaneous development of ecological and taxonomic research in enchytraeids studies is both desirable and feasible, and can lead to mutual benefits: a limited number of nonsexual traits is sufficient for sorting a large number of specimens into taxonomic groups or species; and the probability of finding rare species is increased.

\section{Acknowledgements}

To the German Federal Ministry of Education and Research and to the Conselho Nacional de Desenvolvimento Científico e Tecnológico within the Brazilian-German Mata Atlântica program for support (BMBF; Project 01LB0201; CNPq; Proc. 590042/2006-8). To the Brazilian NGO Sociedade de Pesquisa em Vida Selvagem e Educação Ambiental for permission and substantial support of field work at their reserves Reserva Natural Rio Cachoeira and Reserva Natural Serra do Itaqui. To the Natural History Museum, London, UK, and the Museu de Zoologia da Universidade de São Paulo, Brazil, for loan of type material of South American enchytraeid species for microscopical reinvestigation. To George G. Brown for substantial improvement of the manuscript.

\section{References}

BIHN, J.H.; VERHAAGH, M.; BRÄNDLE, M.; BRANDL, R. Do secondary forests act as refuges for old growth forest animals? Recovery of ant diversity in the Atlantic forest of Brazil. Biological Conservation, v.141, p.733-743, 2008.

BITTENCOURT, E.C.R. Algumas Enchytraeidae (Oligochaeta) de São Paulo. Revista Brasileira de Biologia, v.34, p.369-378, 1974.

ČERNOSVITOV, L. Notes sur les Oligochaeta (Naididées et Enchytraeidées) de l'Argentine. Anales del Museo Argentino de Ciencias Naturales, v.39, p.135-157, 1937.

CHRISTOFFERSEN, M.L. Species diversity and distribution of microdrile earthworms (Annelida, Clitellata, Enchytraeidae) from South America. Zootaxa, v.2065, p.51-68, 2009.

GOTELLI, N.J. A taxonomic wish-list for community ecology. Philosophical Transactions of the Royal Society of London, Series B-Biological Sciences, v.359, p.585-597, 2004.

GRAEFE, U.; SCHMELZ, R.M. Indicator values, strategy types and life forms of terrestrial Enchytraeidae and other microannelids. In: INTERNATIONAL SYMPOSIUM ON ENCHYTRAEIDAE, 3., 1999, Osnabrück. Proceedings. Osnabrück: Universitätsverlag Rasch, 1999. p.59-67.

HÖFER, H.; VERHAAGH, M.; FABRY, R. SOLOBIOMA - Bodenbiota und Biogeochemie in Küstenregenwäldern Südbrasiliens. Umweltwissenschaften und Schadstoff-Forschung, v.19, p.128-131, 2007.

INTERNATIONAL ORGANIZATION FOR STANDARDIZATION. ISO/FDIS 23611-3: soil quality - sampling of soil invertebrates. Part 3: sampling and soil extraction of enchytraeids. Geneva: ISO, 2006.

LIEBSCH,D.; GOLDENBERG, R.; MARQUES, M.C.M. Florística e estrutura de comunidades vegetais em uma cronoseqüência de Floresta Atlântica no Estado do Paraná, Brasil. Acta Botanica Brasilica, v.21, p.983-992, 2007.

MYERS, N.; MITTERMEIER, R.A.; MITTERMEIER, C.G.; FONSECA G.A.B. da; KENT, J. Biodiversity hotspots for conservation priorities. Nature, v.403, p.853-858, 2000.

PROJECT SOLOBIOMA. Project SOLOBIOMA [home page]. Available at: <www.solobioma.ufpr.br $>$. Accessed on: 4 Sept. 2009.

RÖMBKE, J. Enchytraeidae of tropical soils: state of the art, with special emphasis on Latin America. Folia Facultatis Scientiarum Naturalium Universitatis Masarykianae Brunensis, Biologia, v.110, p.157-181, 2007.

RÖMBKE, J.; COLLADO, R.; SCHMELZ, R.M. Abundance, distribution and indicator potential of enchytraeid genera (Enchytraeidae, Clitellata) in secondary forests and pastures of the Mata Atlântica. Acta Hydrobiologica Sinica, v.31, p.139-150, 2007.

RÖMBKE, J.; COLLADO, R.; SCHMELZ, R.M. Oligochaetes (Clitellata) of the Mata Atlântica (Paraná, Brazil): first results of the SOLOBIOMA project. Proceedings of the Estonian Academy of Sciences: Biology, Ecology, v.54, p.302-309, 2005. 
RÖMBKE, J.; SCHMIDT, P.; HÖFER, H. The earthworm fauna of regenerating forests and anthropogenic habitats in the coastal region of Paraná. Pesquisa Agropecuária Brasileira, v.44, p.1040-1049, 2009.

SCHMELZ, R.M. Taxonomy of Fridericia (Oligochaeta, Enchytraeidae). Revision of species with morphological and biochemical methods. Abhandlungen des Naturwissenschaftlichen Vereins in Hamburg (Neue Folge), v.38, p.1-415, 2003.

SCHMELZ, R.M.; COLLADO, R. Revision of Hemienchytraeus stephensoni (Cognetti, 1927) (Enchytraeidae,
Oligochaeta, Annelida). Folia Facultatis Scientiarum Naturalium Universitatis Masarykianae Brunensis, Biologia, v.110, p.67-85, 2007.

SCHMELZ, R.M.; COLLADO, R.; RÖMBKE, J. Mata Atlântica enchytraeids (Paraná, Brazil): the genus Achaeta (Oligochaeta, Enchytraeidae). Zootaxa, v.1809, p.1-35, 2008.

SCHMIDT, P.; DICKOW, K.; ROCHA, A.A.; MARQUES, R.; SCHEUERMANN, L.; RÖMBKE, J.; HÖFER, H. Soil macrofauna and decomposition rates in southern Mata Atlântica rainforests. Ecotropica, v.14, p.89-100, 2008.

Received on November 1 1t, 2008 and accepted on June 15, 2009 